\title{
Genetics and Incorporation of Glandular Trichomes and Polyphenol Oxidase Activity into an Advanced Solanum phureja-S. stenotomum Diploid Potato Population
}

\author{
Roger L. Vallejo ${ }^{1}$, Wanda W. Collins ${ }^{2}$, and Rocco D. Schiavone ${ }^{3}$ \\ Department of Horticultural Science, North Carolina State University, Raleigh, NC 27695-7609 \\ Additional index words. backcrossing, heritability, potato breeding, family selection, Solanum spp., genotypic correlation, \\ phenotypic correlation, Solanum berthaultii
}

\begin{abstract}
Preliminary data on the genetics of glandular trichomes and the feasibility of incorporating A and B glandular trichomes and polyphenol oxidase (PPO) activity from Solanum berthaultii Hawkes (Ber) into an advanced S. phureja Juz. et Buk.-S. stenotomum Juz. (Phu-Stn) diploid potato population are presented. A random sample of four Phu-Stn clones was intercrossed with a sample of three Ber progenies (pollen bulk per progeny) segregating for high density of A and B glandular trichomes. Nine $F_{1}$ families [(Phu-Stn) $x$ Ber] were evaluated over two experiments in the greenhouse for $A$ and $B$ trichome density $\left(5 \mathrm{~mm}^{2}\right.$ of abaxial surface) and PPO activity 45 days after planting. A completely randomized design in an experimental hierarchical classification arrangement was used to quantify the genetic variability and to estimate broad-sense heritabilities (defined on an individual basis) for the attributes under study. To characterize the inheritance of these attributes further and to estimate narrow-sense heritabilities, fifteen backcross (BC) families were evaluated in a randomized complete-block design with three replications and analyzed by half-sib family analysis. Phenotypic and genotypic correlations between these attributes were also estimated. In the $F_{1}$ families, broad-sense heritabilities were 0.59 and 0.41 for density of $A$ and $B$ trichomes, respectively. In the BC population, narrow-sense heritabilities were 0.15 and 0.08 for A trichome density and PPO activity, respectively; expression of B trichomes was almost absent in this generation. Genotype $\times$ environment interaction was significant for density of A trichomes and highly significant for density of B trichomes in $F_{1}$ families. There was some level of positive association between density of $A$ and $B$ trichomes and PPO activity. Additive genetic variance of these attributes was very low in this study; therefore, selection schemes based on family selection and progeny testing would be an appropriate breeding strategy for improving these traits.
\end{abstract}

Two Andean diploid potato species, Solanum phureja (Phu) and S. stenotomum (Stn), have been shown to be valuable sources of germplasm for some desired characters in potato. Haynes (1980) developed a Phu-Stn hybrid population with high levels of dry matter and alternaria leaf-blight resistance. Progress in erwinia soft-rot resistance and heat tolerance has also been made (Haynes, 1980; Hidalgo and Echandi, 1982). The hybrid population was found to have moderate resistance to potato virus X (PVX) but not to potato virus Y (PVY). Development of immunity or a high level of resistance to PVY is needed to preserve and use fully the immense value of this germplasm.

The wild diploid potato species, S. berthaultii (Ber), is a valuable source of resistance to insects including aphids, the vector of PVY (Tingey et al., 1982). Two types of glandular trichomes are associated with this resistance: a short type with a four-lobed head (type A) and a longer multicellular type with an ovoid gland at its tip (type B) (Gibson and Turner, 1977).

Polyphenoloxidase (PPO) and peroxidase (PO) activities have been found in S. berthaultii trichomes (Ryan et al., 1982). The involvement of PPO and/or PO activity in enzymatic browning reaction and its importance in trichome-mediated resistance to aphids have been demonstrated by Ryan et al. (1983).

Breeding for resistance to aphids in potatoes should ideally

\footnotetext{
Received for publication 9 Sept. 1993. Accepted for publication 21 Jan. 1994. This research was submitted in partial fulfillment of the requirements for a PhD by R.L. Vallejo and was entirely supported by the International Potato Center, Lima, Peru. The cost of publishing this paper was defrayed in part by the payment of page charges. Under postal regulations, this paper therefore must be hereby marked advertisement solely to indicate this fact.

${ }^{1}$ Virology postdoctoral. Current address: Univ. of Florida, Gulf Coast Research and Education Center, 5007 60th St. East., Bradenton, FL 34203.

${ }^{2}$ Professor.

${ }^{3}$ Research technician.
}

focus on resistance mechanisms that interfere with the insects' abilities to transmit PVY. The most convincing and simplest explanation for the reduced vector potential of aphids on Ber and the adverse influence of glandular trichomes on probing behavior is the mechanical interference with probing by trichome exudate and reduced ability of alate aphids to disperse from the adhesive foliage of the plants (Lapointe et al., 1987). Existence of immunity to PVY (Fernandez-Northcote, 1983; Mendoza, 1980; Muñoz et al., 1975) may seem to make the issue irrelevant. However, glandular trichomes could provide a first line of defense, reducing inoculum pressure and, thereby, the possibility of the occurrence of a new resistance-breaking virus strain (Lapointe et al., 1987).

The objectives of this research were to a) estimate components of genetic variance and heritabilities for density of A and B glandular trichomes and polyphenol oxidase (PPO) activity, b) estimate effects of genotype $\times$ environment interaction, c) estimate correlations between traits under study, and d) explore the feasibility of incorporating A and B trichomes and PPO activity into a hybrid $\mathrm{Phu}-$ Stn diploid potato population and propose a selection scheme for improving these traits.

\section{Materials and Methods}

Four Phu-Stn advanced hybrid clones were intercrossed to three plant introductions of $S$. berthaultii (Ber) segregating for A and B glandular trichomes: PI265857, PI265858, and PI473331 from the Inter-Regional Potato Introduction Station, Sturgeon Bay, Wis.

To quantify genetic variability and to estimate broad-sense heritabilities $(\mathrm{H})$ for $\mathrm{A}$ and $\mathrm{B}$ trichome density, nine $\mathrm{F}_{1}$ families [(Phu-Stn) $x$ Ber] were evaluated in two experiments under greenhouse conditions. Experiments 1 and 2 included four and nine plants per family, respectively. The density of A and B 
glandular trichomes was evaluated 45 days after planting. Trichome density was assessed in $5 \mathrm{~mm}^{2}$ of abaxial leaf surface under a $\times 64$ microscope using three leaflets sampled from the middle portion of each plant and two spots per leaflet. Spots for trichome countings were located between secondary veins, avoiding main veins and leaflet borders. A completely randomized design in an experimental hierarchical classification arrangement; i.e., families, plants per family, leaves per plant, was used (Steel and Torrie, 1980). The combined analysis included experiments (two), families per experiment (nine), plants per family (four and nine), leaflets per plant (three), and spots per leaflet (two). For the statistical analysis, the method of least squares in a general linear model (PROC GLM) (SAS Institute, 1985) was used, and for estimating variance components, the method of maximum likelihood in a general linear model (PROC VARCOMP) (SAS Institute, 1985) was used.

A pollen bulk from $\mathrm{F}_{1}$ clones selected for a high density of A and B glandular trichomes was used to backcross to Phu-Stn clones selected for high levels of specific gravity and erwinia soft-rot resistance $\left[(\mathrm{Phu}-\mathrm{Stn}) \times \mathrm{F}_{1}\right.$ bulk] to generate a backcross $(\mathrm{BC})$ population. Fifteen half-sib families from this BC population were evaluated in the greenhouse to quantify genetic variability further and to estimate narrow-sense heritabilities $\left(\mathrm{h}^{2}\right)$ for $\mathrm{A}$ and $\mathrm{B}$ trichome density and PPO activity. The density of A and B trichomes was evaluated using a randomized complete-block design with three replications, fifteen families, ten plants per family, two leaves per plant, and two spots per leaf. PPO activity was assessed following the procedures proposed by Avé et al. (1986). Analyses of variance were done using PROC GLM (SAS Institute, 1985) and variance components were estimated using PROC VARCOMP (SAS Institute, 1985).

The genetic components of variance were estimated under these assumptions: a) normal diploid and solely Mendelian inheritance; b) no environmental correlations among progenies; c) the parents are not inbred and can be considered random members of some noninbred population; d) experimental errors are independent; and e) linkage equilibrium (Cockerham, 1963). H, defined as the ratio of total genetic variance to phenotypic variance, and $\mathrm{h}^{2}$, defined as the ratio of additive genetic variance to phenotypic variance, were estimated on an individual plant basis using standard procedures of quantitative traits analyses (Dudley and Moll, 1969; Hallauer and Miranda, 1988; Nyquist, 1991).

In $\mathrm{F}_{1}$ and $\mathrm{BC}$ families, phenotypic correlations between $\mathrm{A}$ and $\mathrm{B}$ trichome density and PPO activity were estimated using procedures to estimate Pearson correlations (PROC CORR) (SAS Institute, 1985). Similarly, analysis of covariance and estimation of overall phenotypic and genotypic correlations between these traits were done combining PROC GLM and multivariate analysis of variance (PROC MANOVA) (SAS Institute, 1985).

\section{Results and Discussion}

The combined analysis over experiments for density of A and $\mathrm{B}$ trichomes is shown in Table 1. Differences between experiments were highly significant for both A and B trichomes. Differences among families were not significant. The experiment $\times$ family interaction was significant and highly significant for $\mathrm{A}$ and $\mathrm{B}$ trichomes, respectively. These results indicate that the effects of genotype $\times$ environment interaction could be significant in the expression of these attributes. Thus, environmental conditions for the expression of both types of glandular trichomes were more favorable in Expt. 1 than in Expt. 2 (Table 2). Family rankings also changed over experiments. Differences among plants within families and among leaves within plants for density of both trichomes were also highly significant (Table 1), showing that trichome densities are highly variable from plant to plant within the same family and even among leaves and spots from the same plant and resulting in high coefficients of variability (CVs).

From the combined analysis of $\mathrm{F}_{1}$ families, genetic variance components were estimated (Table 1 ). $\mathrm{H}$ was estimated as 0.59 for A trichome density and 0.41 for B trichome density. Using a halfsib family analysis with the BC population, $\mathrm{h}^{2}$ was estimated as 0.15 and 0.08 for A trichome density and PPO activity, respectively (Table 3). B trichomes were not expressed in this BC population. The $\mathrm{CV}$ of $\mathrm{PPO}$ activity was lower than that of $\mathrm{A}$ trichome density.

The low $\mathrm{h}^{2}$ estimates obtained from a half-sib family analysis in the $\mathrm{BC}$ population indicate that the medium to high $\mathrm{H}$ levels found in the $\mathrm{F}_{1}$ generation were mostly due to nonadditive genetic effects. Therefore, it seems that the inheritance of density of A and B

Table 1. Analysis of variance and estimates of variance components ${ }^{\mathrm{z}}$ for $\mathrm{A}$ and $\mathrm{B}$ trichome density in $\mathrm{F}_{1}[(\mathrm{Phu}-\mathrm{Stn}) \times \mathrm{Ber}]$ diploid potato families.

\begin{tabular}{|c|c|c|c|c|c|}
\hline \multirow[b]{2}{*}{$\begin{array}{l}\text { Source of } \\
\text { variation }\end{array}$} & \multicolumn{3}{|c|}{ Trichome A } & \multicolumn{2}{|c|}{ Trichome B } \\
\hline & df & MS & $\begin{array}{l}\text { Variance } \\
\text { component }\end{array}$ & MS & $\begin{array}{l}\text { Variance } \\
\text { component }\end{array}$ \\
\hline$\overline{\text { Experiment (E) }}$ & 1 & $3653.77^{* *}$ & 4.79 & $15874.48^{* *}$ & 22.56 \\
\hline Family (F) & 8 & 958.19 & 4.61 & 1887.37 & 0.63 \\
\hline $\mathrm{E} \times \mathrm{F}$ & 8 & $601.40^{*}$ & 9.67 & $1859.81^{* *}$ & 46.41 \\
\hline Plant $(\mathrm{E} \times \mathrm{F})$ & 92 & $218.27^{* *}$ & 25.76 & $307.64^{* *}$ & 40.55 \\
\hline Leaf $(E \times F \times$ plant $)$ & 220 & $68.38^{* *}$ & 17.43 & $71.33^{* *}$ & 16.17 \\
\hline Error & 328 & 33.61 & 33.62 & 39.13 & 39.18 \\
\hline $\mathrm{CV}$ & & & 76.5 & & 25.5 \\
\hline$\sigma_{\mathrm{G}}^{2}$ & & & 30.77 & & 41.18 \\
\hline$\sigma_{P}^{2}$ & & & 51.45 & & 99.51 \\
\hline $\operatorname{Var}\left(\sigma_{G}^{2}\right)$ & & & 81.87 & & 449.78 \\
\hline $\mathrm{H}^{\mathrm{x}}$ & & & 0.59 & & 0.41 \\
\hline $\mathrm{SE}(\mathrm{H})$ & & & 0.17 & & 0.21 \\
\hline
\end{tabular}

${ }^{\mathrm{z}} \sigma_{\mathrm{G}}^{2}=$ genetic variance; $\sigma_{\mathrm{P}}^{2}=$ phenotypic variance; $\operatorname{var}\left(\sigma_{\mathrm{G}}^{2}\right)=$ variance of genetic variance.

${ }^{y}$ Experiment $=2$, family $=9$, plants per family $=4$ (Expt. 1) and 9 (Expt. 2), leaves per plant $=3$, spots per leaf $=2$.

${ }^{\mathrm{x}} \mathrm{H}=$ broad-sense heritability.

,*** Significant at $P=0.05$ or 0.01 , respectively. 
Table 2. Means of A and B trichome density ${ }^{\mathrm{z}}$ in $\mathrm{F}_{1}[(\mathrm{Phu}-\mathrm{Stn}) \times \mathrm{Ber}]$ diploid potato families.

\begin{tabular}{|c|c|c|c|c|}
\hline \multirow[b]{2}{*}{ Family } & \multicolumn{2}{|c|}{ Type A } & \multicolumn{2}{|c|}{ Type B } \\
\hline & Expt. $1^{\mathrm{y}}$ & Expt. 2 & Expt. 1 & Expt. 2 \\
\hline 72P12-3 x PI265857 & $23.6(1)^{x}$ & $7.8(3)$ & $20.8(9)$ & $14.0(9)$ \\
\hline 70P8-2 x PI473331 & $19.3(2)$ & $6.0(6)$ & $45.4(1)$ & $18.0(7)$ \\
\hline $66 \mathrm{P} 25-3 \times \mathrm{PI} 265858$ & $11.8(3)$ & $6.4(4)$ & $24.2(6)$ & $22.6(3)$ \\
\hline $66 \mathrm{P} 25-3 \times$ PI473331 & $11.7(4)$ & $8.5(2)$ & $36.6(4)$ & $22.7(2)$ \\
\hline 66P8-7 x PI473331 & $10.6(5)$ & $6.0(5)$ & $23.8(7)$ & $19.4(5)$ \\
\hline 70P8-2 x PI265858 & $10.4(6)$ & $3.2(8)$ & $30.3(5)$ & $33.2(1)$ \\
\hline 70P8-2 x PI265857 & $6.4(7)$ & $11.0(1)$ & $41.4(2)$ & $21.7(4)$ \\
\hline 66P8-7 x PI265858 & $3.6(8)$ & $4.3(7)$ & $40.9(3)$ & $17.4(8)$ \\
\hline 66P8-7 x PI265857 & $3.5(9)$ & $1.1(9)$ & $20.8(8)$ & $19.2(6)$ \\
\hline Mean & 11.2 & 6.0 & 31.5 & 20.9 \\
\hline SD & 6.7 & 2.9 & 9.8 & 5.4 \\
\hline
\end{tabular}

${ }^{\mathrm{z} N u m b e r}$ of glandular trichomes per $5 \mathrm{~mm}^{2}$ based on four (Expt. 1) and nine (Expt. 2) plants per progeny, three leaves per plant, and two spots per leaf.

${ }^{\mathrm{y} E x p e r i m e n t s} 1$ and 2 were evaluated in November 1990 and February 1991, respectively.

${ }^{x}$ Rank per experiment.

Table 3. Variance components ${ }^{\mathrm{z}}$ and narrow-sense heritability $\left(\mathrm{h}^{2}\right)$ estimates for A and B trichome density and polyphenol oxidase (PPO) activity using half-sib family analysis in a backcross ${ }^{y}$ potato population.

\begin{tabular}{lrccc}
\hline \hline & & \multicolumn{3}{c}{ Variance components } \\
\cline { 3 - 5 } Source & $\mathrm{df}$ & $\mathrm{A}$ & $\mathrm{B}$ & $\mathrm{PPO}$ \\
\hline Replication & 2 & 0.1743 & 0.0005 & 0.0000 \\
Family & 14 & 0.0578 & 0.0000 & 0.00002 \\
Replication $\times$ family & 28 & 0.3043 & 0.0000 & 0.00055 \\
Sampling error & 382 & 1.1873 & 0.0088 & 0.00045 \\
$\mathrm{CV}$ & & 23.1 & 9.0 & 2.0 \\
$\sigma^{2}$ & & 0.2312 & 0.000 & 0.00008 \\
$\sigma^{2}$ & 1.5494 & 0.0088 & 0.00102 \\
$\mathrm{~h}^{2} \pm \mathrm{SE}$ & & $0.15 \pm 0.11$ & 0.000 & $0.08 \pm 0.19$ \\
$\mathrm{z}^{2}{ }^{2}=$ additive genetic variance; $\sigma^{2}=$ phenotypic variance & & &
\end{tabular}

${ }^{{ }^{\mathrm{Z}} \sigma^{2}}=$ additive genetic variance; $\sigma_{\mathrm{P}}^{2}=$ phenotypic variance.

$\mathrm{y}\left[(\mathrm{Phu}-\mathrm{Stn}) \times \mathrm{F}_{1}\right.$ bulk].

glandular trichomes and PPO activity could be due mainly to nonadditive genetic effects and that the additive component is very low.

Expression of $\mathrm{B}$ trichomes was high in the $\mathrm{F}_{1}$ population but almost completely lost in the BC population. Kalazich and Plaisted (1991) reported the same phenomenon and showed that B trichomes are recovered when $\mathrm{BC}$ siblings are intermated or selfed. It has been proposed that a deficiency of genes from the donor parent or an excess of genes from the recurrent parent in BCs is due to structural genomic differentiation (Rick, 1969; Stephens, 1949; Zamir and Tadmor, 1987). This tendency to preserve and favor such groups of genes would greatly reduce the assortment of germplasm of the two species, and it should be considered in planning breeding programs aimed at introgressing genes from wild species into cultivated crops.

Phenotypic correlations between the density of A and B trichomes in the $\mathrm{F}_{1}$ families within each experiment were estimated (Table 4). Eight families showed from a medium to a high positive phenotypic correlation ( 0.47 to 0.96$)$. Four families showed poor or low positive correlations ( 0.16 to 0.33 ), and seven families showed negative phenotypic correlations $(-0.17$ to -0.72$)$. Pooling both $\mathrm{F}_{1}$ experiments, the overall genotypic correlation (Table 5) between the density of A and B trichomes was positive and highly significant $\left(\mathrm{r}_{\mathrm{GAB}}=0.26\right)$. In the $\mathrm{BC}$ population, significant and positive phenotypic correlations between density of A trichomes and PPO activity were also found (Table 6). These results suggest that the densities of A and B trichomes and PPO activity have some level of positive association, which could facilitate the development of potato populations exhibiting simultaneous high levels of these traits.

Furthermore, inconsistencies in correlations per family over experiments seem to be due to an inherently high variability of trichome density, significant effects of genotype $\times$ environment interaction, and family size or sampling. From all of these factors, family size seems to be the most important for the increased incidence of inconsistent and negative correlations. Thus, in Expt. 1 (family size $=$ four plants), more negative correlations were found than in Expt. 2 (family size = nine); additionally, when pooling both experiments, the overall genotypic correlation was positive and quite similar to the phenotypic correlations estimated in the $\mathrm{BC}$ experiment (family size $=10$ ).

Progeny means for type A trichome density ranged from 1.1 to 23.6 per $5 \mathrm{~mm}^{2}$, with means of 11.2 and 6.0 for Expts. 1 and 2, respectively (Table 2). Type B trichome density ranged from 14.0 to 45.4, with means of 31.5 and 20.9 for Expts. 1 and 2, respectively (Table 2). These family means illustrate the range of variability and potential for selecting segregating families for a high density of glandular trichomes of either type A or B. The dispersion found in family means and the positive associations discussed above suggest the possibility of selecting segregating families for a high density of both glandular trichomes.

In addition, the highly significant differences detected among 
Table 4. Phenotypic correlations (Pearson) between A and B glandular trichomes in $\mathrm{F}_{1}[(\mathrm{Phu}-\mathrm{Stn}) \times \mathrm{Ber}]$ diploid potato families.

\begin{tabular}{lcc}
\hline & \multicolumn{2}{c}{ Phenotypic correlation } \\
\cline { 2 - 3 } Family & Expt. 1 & Expt. 2 \\
\hline 66 P8-7 x PI265857 & $-0.72^{*}$ & $0.77^{*}$ \\
70P8-2 x PI265857 & -0.22 & $0.67^{*}$ \\
72P12-3 x PI265857 & 0.47 & 0.33 \\
66P8-7 x PI265858 & -0.17 & 0.26 \\
66P25-3 x PI265858 & $0.74^{*}$ & 0.32 \\
70P8-2 x PI265858 & -0.29 & $-0.70^{*}$ \\
66P8-7 x PI473331 & -0.50 & -0.40 \\
66P25-3 x PI473331 & $0.96^{* *}$ & $0.91^{* *}$ \\
70P8-2 x PI473331 & 0.57 & 0.16 \\
72P12-3 x PI473331 & $0.88^{*}$ & -- \\
\hline **** Si
\end{tabular}

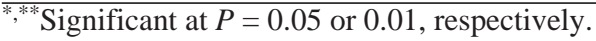

Table 5. Estimates of covariance components $\mathrm{s}^{\mathrm{Z}}$ and overall phenotypic and genotypic correlations between $\mathrm{A}$ and $\mathrm{B}$ trichome density in an $\mathrm{F}_{1}$ [(Phu-Stn $) \times$ Ber] diploid potato population.

\begin{tabular}{|c|c|c|c|}
\hline $\begin{array}{l}\text { Source of } \\
\text { variation }\end{array}$ & $\mathrm{df}$ & $\begin{array}{c}\text { Mean cross } \\
\text { product }\end{array}$ & $\begin{array}{l}\text { Covariance } \\
\text { component }\end{array}$ \\
\hline Experiment (E) & 1 & $7615.9^{* *}$ & 23.95 \\
\hline Family (F) & 8 & -69.4 & 1.02 \\
\hline $\mathrm{E} \times \mathrm{F}$ & 8 & $-143.2^{*}$ & -5.79 \\
\hline Plants $(\mathrm{E} \times \mathrm{F})$ & 92 & $65.3^{* *}$ & 8.12 \\
\hline Leaf $(E \times F \times$ plant $)$ & 220 & $16.6^{* * *}$ & 4.90 \\
\hline Error & 328 & 6.8 & 6.80 \\
\hline$\sigma_{\mathrm{PAB}}$ & & & 2.38 \\
\hline$r_{\mathrm{PAB}}$ & & & 0.03 \\
\hline$\sigma_{\mathrm{GAB}}$ & & & 9.14 \\
\hline$r_{\mathrm{GAB}}^{\mathrm{GAB}}$ & & & $0.26^{* *}$ \\
\hline \multicolumn{4}{|c|}{$\begin{array}{l}{ }^{\mathrm{z}} \sigma_{\mathrm{PAB}}=\text { phenotypic covariance between } \mathrm{A} \text { and } \mathrm{B} \text { trichome density; } \sigma_{\mathrm{GAB}} \\
=\text { genotypic covariance between } \mathrm{A} \text { and } \mathrm{B} \text { trichome density; } \mathrm{r}_{\mathrm{PAB}}= \\
\text { phenotypic correlation between } \mathrm{A} \text { and } \mathrm{B} \text { trichome density; } \mathrm{r}_{\mathrm{GAB}}=\text { geno- } \\
\text { typic correlation between } \mathrm{A} \text { and } \mathrm{B} \text { trichome density. } \\
{ }^{* * * *} \text { Significant at } P=0.05 \text { or } 0.01 \text {, respectively. }\end{array}$} \\
\hline
\end{tabular}

plants within families (Table 1) and the positive association found between density of both types of trichomes permits the selection of $\mathrm{F}_{1}$ clones with a high density of $\mathrm{A}$ and $\mathrm{B}$ trichomes (Table 7). Genotypes carrying both attributes are highly desirable in potato breeding for insect resistance because plants bearing both types of trichomes have been reported to be more resistant to green peach aphid than those with type A trichomes alone (Gibson, 1979).

It has been shown that several cultivated potatoes have A glandular trichomes and that potato plants are resistant to insects only if their trichome biochemical component resembles that of $S$. tarijense, S. polyadenium, or $S$. berthaultii (Avé et al., 1986); therefore, assessing PPO activity should be considered an important component in the development of populations with resistance to insects, since it indicates the amount of oxidases present in glandular trichomes.

It was recently found that $\mathrm{Phu}-\mathrm{Stn}\left(21.7\right.$ trichomes $\left./ 5 \mathrm{~mm}^{2}\right)$ has a higher density of A trichomes than Ber (2.3); when crossing PhuStn with Ber, the density of A trichomes in $F_{1}(6.3)$ is higher than that of Ber, but lower than that of Phu-Stn; however, the size of the glands in Phu-Stn was smaller than that of Ber and $\mathrm{F}_{1}$. Type B trichomes were not found in Phu-Stn; the parent Ber (27.0) had higher levels of $B$ trichomes than those of $F_{1}$ (21.0). While Ber (0.42, optical density at $470 \mathrm{~nm})$ and $F_{1}(0.39)$ showed a higher level of PPO activity than that of Phu-Stn (0.26), they were also
Table 6. Phenotypic correlations between density of A glandular trichomes and polyphenol oxidase (PPO) activity in a backcross ${ }^{\mathrm{z}}$ potato population.

\begin{tabular}{lc}
\hline \hline Replication & $\begin{array}{c}\text { A-PPO phenotypic } \\
\text { correlation }\end{array}$ \\
\hline I & $0.29^{* *}$ \\
II & $0.28^{* *}$ \\
III & $0.21^{*}$ \\
Overall & $0.25^{* *}$
\end{tabular}

${ }_{\mathrm{Z}}^{\mathrm{Z}}(\mathrm{Phu}-\mathrm{Stn}) \times \mathrm{F}_{1}$ bulk $]$.

**** Significant at $P=0.05$ or 0.01 , respectively.

Table 7. Selected ${ }^{\mathrm{z}}$ genotypes for high density of A and B glandular trichomes from evaluations of $\mathrm{F}_{1}\{(\mathrm{Phu}-\mathrm{Stn}) \times$ Ber $\}$ diploid potato families.

\begin{tabular}{|c|c|c|}
\hline \multirow[b]{2}{*}{ Clone } & \multicolumn{2}{|c|}{ Trichome type } \\
\hline & A & $\mathrm{B}$ \\
\hline$\overline{(72 P 12-3 ~ x ~ P I 265857) 4 ~}$ & 29.2 & 21.2 \\
\hline$(70 \mathrm{P} 8-2 \times$ PI473331)4 & 24.5 & 44.2 \\
\hline$(66 \mathrm{P} 8-7 \times$ x PI473331)1 & 24.3 & 22.8 \\
\hline$(66 \mathrm{P} 25-3 \times$ PI473331)2 & 23.2 & 42.8 \\
\hline (72P12-3 x PI265857)1 & 22.7 & 23.8 \\
\hline (70P8-2 x PI473331)1 & 21.7 & 70.7 \\
\hline$(66 \mathrm{P} 25-3 \times \mathrm{PI} 265858) 3$ & 20.3 & 29.3 \\
\hline$(72 \mathrm{P} 12-3 \times \mathrm{PI} 265857) 2$ & 19.0 & 17.3 \\
\hline (70P8-2 x PI473331)2 & 16.8 & 32.8 \\
\hline$(70 P 8-2 \times$ PI265858)4 & 16.5 & 23.7 \\
\hline$(66 \mathrm{P} 25-3 \times \mathrm{PI} 265858) 2$ & 14.5 & 22.5 \\
\hline (70P8-2 x PI473331)3 & 14.3 & 34.2 \\
\hline$(66 \mathrm{P} 25-3 \times \mathrm{PI} 473331) 3$ & 13.5 & 35.5 \\
\hline$(70 \mathrm{P} 8-2 \times \mathrm{PI} 265857) 3$ & 12.5 & 41.5 \\
\hline (70P8-2 x PI265857)2 & 11.2 & 48.7 \\
\hline Selected population mean \pm SD & $18.9 \pm 5.3$ & $34.1 \pm 14.0$ \\
\hline Original Population mean \pm SD & $10.2 \pm 1.5$ & $31.1 \pm 1.4$ \\
\hline
\end{tabular}

${ }^{\mathrm{z}}$ Selected $=31.2 \%$ of original population was selected.

quite similar to each other; Ber was slightly higher than $\mathrm{F}_{1}$ (Vallejo et al., 1994).

To reduce the high levels of variability observed in the evaluation of potato glandular trichome density, it would be advisable to consider the following in future experiments. First, completely randomized or randomized complete-block designs of at least three replications should be used. In fact, the choice of the experimental design will depend on the number of entries or families being tested and the uniformity of the experimental units used, either at the greenhouse or in the field. Second, the experiments should be replicated over a period of time or at different locations, since a high genotype $\times$ environment interaction for glandular trichome density was observed. Third, the family size or number of evaluated individuals per family should consist of at least 10 plants. In addition, at least three leaflets per plant and three spots per leaflet should be assessed for glandular trichome density. Fourth, trichome countings should be assessed consistently on defined areas of the potato leaflet for the whole experiment, since it was observed that the trichome density is higher on main and secondary veins and leaflet borders than on areas located between veins.

In general, these results suggest that the high density of glandular trichomes and high levels of PPO activity were successfully transmitted from the wild Ber to the advanced Phu-Stn population. 
However, for increasing frequencies of genes controlling these traits in this breeding population, considering the low $\mathrm{h}^{2}$ estimates, the apparent predominance of nonadditive genetic variance in the control of these traits and the complexities found in the segregation of B trichomes, selection schemes based on family selection and progeny testing would be an appropriate breeding procedure.

\section{Literature Cited}

Avé, D.A., N.T. Eannetta, and W.M. Tingey. 1986. A modified enzymic browning assay for potato glandular trichomes. Amer. Potato J. 63:553558.

Cockerham, C.C. 1963. Estimation of genetic variances, p. 53-93. In: W.D. Hanson and H.F. Robinson (eds.). Statistical genetics and plant breeding. Natl. Acad. Sci.-Natl. Res. Council, Washington, D.C. Publ. 982.

Dudley, J.W. and R.H. Moll. 1969. Interpretation and use of estimates of heritability and genetic variances in plant breeding. Crop Sci. 9:257262.

Fernandez-Northcote, E.N. 1983. Prospects for stability of resistance to potato virus Y. Research for the potato in the year 2000. Proc. Intl. Congr. Celebration 10th Anniversary Intl. Potato Center, Lima, Peru, 1982.

Gibson, R.W. 1979. The geographical distribution, inheritance and pest resisting properties of sticky-tipped foliar hairs on potato species. Potato Res. 22:223-236.

Gibson, R.W. and R.H. Turner. 1977. Insect-trapping hairs on potato plants. PANS 22:272-277.

Hallauer, A.R. and J.B. Miranda, Fo. 1988. Quantitative genetics in maize breeding. 2nd ed. Iowa State Univ. Press, Ames.

Haynes, F.L. 1980. Progress and future plans for the use of Solanum phureja-S. stenotomum populations. Intl. Potato Center Planning Conf. Potatoes, Lima, Peru, Nov. 1980.

Hidalgo, O.A. and E. Echandi. 1982. Evaluations of potato clones for tuber and stem rot induced by Erwinia chrysanthemi. Amer. Potato J. 59:585-592.
Kalazich, J.C. and R.L. Plaisted. 1991. Association between trichome characters and agronomic traits in Solanum tuberosum (L.) XS. berthaultii (Hawkes) hybrids. Amer. Potato J. 68:833-847.

Lapointe, S.L., W.M. Tingey, and T.A. Zitter. 1987. Potato virus Y transmission reduced in an aphid-resistant potato species. Phytopathology 77:819-822.

Mendoza, H.A. 1980. Sources of virus resistance in the genus Solanum. Strategy for virus management in potatoes. Rpt. Planning Conf. Intl. Potato Center, Lima, Peru, 21-25 Apr. 1980. p. 84-88.

Muñoz, F.J., R.L. Plaisted, and H.D. Thurston. 1975. Resistance to potato virus Y in Solanum tuberosum ssp. andigena. Amer. Potato J. 52:107115.

Nyquist, W.E. 1991. Estimation of heritability and prediction of selection response in plant populations. Critical Rev. Plant Sci. 10(3):235-322.

Ryan, J.D., P. Gregory, and W.M. Tingey. 1982. Phenolic oxidase activities in glandular trichomes of Solanum berthaultii. Phytochemistry 21:1885-1887.

Ryan, J.D., P. Gregory, and W. M. Tingey. 1983. Glandular trichomes: enzymic browning assays for improved selection of resistance to the green peach aphid. Amer. Potato J. 60:861-868.

Rick, C.M. 1969. Controlled introgression of chromosomes of Solanum penelli into Lycopersicon esculentum: Segregation and recombination. Genetics 62:753-768.

SAS Institute. 1985. SAS user's guide: Statistics. SAS Inst., Cary, N.C. Steel, R.G.D. and J.H. Torrie. 1980. Principles and procedures of statistics. 2nd ed. McGraw-Hill, New York.

Stephens, S.G. 1949. The cytogenetics of speciation in Gossypium. I. Selective elimination of the donor parent genotype in interspecific backcrosses. Genetics 34:627-637.

Tingey, W.M., R.L. Plaisted, J.E. Laubengayer, and S.A. Mehlenbacher. 1982. Green peach aphid resistance by glandular trichomes in Solanum tuberosum X S. berthaultii hybrids. Amer. Potato J. 59:241-251.

Vallejo, R.L., Collins, W.W., and R.H. Moll. 1994. Inheritance of A and B glandular trichome density and polyphenol oxidase activity in diploid potatoes. J. Amer. Soc. Hort. Sci. 119:829-832.

Zamir, D. and Y. Tadmor. 1987. Unequal segregation of nuclear genes in plants. Bot. Gaz. 147:355-358. 